\title{
A Novel Rotating Disk System for Disintegration of Excess Sludge
}

\author{
Ming yang Zhang, Yun Xiang, and Jian wei Du \\ South China Institute of Environmental Sciences, the Ministry of Environment Protection of PRC, Guangzhou 510000, China \\ Correspondence should be addressed to Jian wei Du; dujianwei@scies.org
}

Received 8 April 2016; Revised 14 June 2016; Accepted 16 June 2016

Academic Editor: Wenshan Guo

Copyright ( 2016 Ming yang Zhang et al. This is an open access article distributed under the Creative Commons Attribution License, which permits unrestricted use, distribution, and reproduction in any medium, provided the original work is properly cited.

Conventional activated sludge treatment process has been widely employed to deal with a variety of municipal and industrial waste water, but the production of sludge by this method is considerable. It is urgent to find an appropriate method which can solve this problem. Shear force produced by rotating disk system (a cell lysis system) was employed to break cell wall of sludge microorganism in order to release intracellular materials which can be reused as nutrient materials for metabolism of other sludge microorganisms in this study. Special feature on surfaces of disks had been proved to be a novel improvement which can improve disintegration effect apparently. Ultrasonic system can further promote minimization of excess sludge after treatment by rotating disk system in shorter time.

\section{Introduction}

Activated sludge treatment process produces excess biomass as excess sludge which is difficult and expensive to dispose. Sludge management has been the main problem of waste water treatment plants (WWTPs) because it costs $60 \%$ of total plant capital cost [1]. With increasing public environmental demands, more and more WWTPs are building in China so as to improve water environment; however large quantity of excess sludge as by-product which is unpleasant for its large volume and offensive odor makes huge stress on excess sludge treatment.

Incineration, ocean discharge, landfill, and composting are common sludge disposal methods used over many years. However these common methods are no longer reliable because of economic constraint and negative effect on environment. More and more stringent regulations for excess sludge treatment have promulgated in developed countries; thus management and treatment of excess sludge have been one of the most stringent challenges in biological sewage treatment field [2].

According to these demands, many kinds of efficient and economical methods have been researched. With classification, the excess sludge minimization approaches are mainly divided into two categories: (1) excess sludge minimization through posttreatment and (2) in situ excess sludge minimization in the process of sewage treatment [3]. Posttreatment refers to excess sludge minimization which has been produced during sewage treatment process; various methods relying on single or combination of physical, chemical, and biological technology had been researched [4-6]. With comparison and investigation, shortcomings of posttreatment including high operational complexity and expense, especially high energy consumption, restricted large-scale application of this method, whereas in situ excess sludge minimization treatment not only avoided these shortcomings but also displayed prominent advantages. The most apparent advantage compared with posttreatment is that this method can minimize excess sludge production from source of activated sludge treatment process. Some researchers have already demonstrated promising application of in situ excess sludge minimization treatment $[7,8]$; thus feasible and efficient in situ excess sludge minimization technology will be very considerable and promising. In recent years, many researchers have investigated different kinds of in situ excess sludge minimization method with physical, chemical, and biological technology in laboratory and pilot plant. 


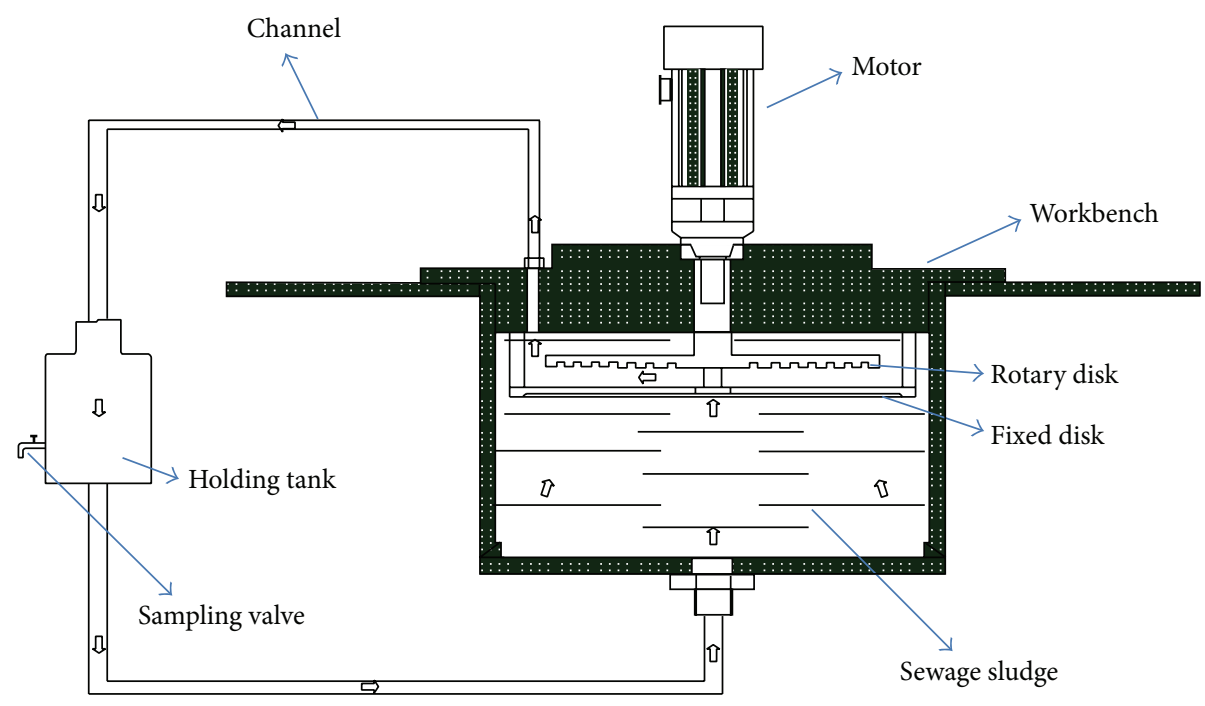

FIGURE 1: Schematic diagram of rotating disk system.

Rotating disk system, a cell lysis system, used shear stress produced by rotating disk to destroy cell wall of microorganism and result in the sludge disruption because intracellular contents are reused as substrate by other microorganism cells for their metabolism. With comparison of other sludge disintegration methods, some advantages of rotating disk system can be found such as no consumption of chemical reagents [9], low energy demand, simple operation, and wide range of applicability because it can deal with the viscosity feature of excess sludge. This system was expected to reduce excess sludge production with characteristics of simple operation and high efficiency. The main objective of this study was to investigate the effects of a novel rotating disk system on sludge disintegration. Optimal parameters as rotating speed, distance between disks, and special features on disks were also investigated. In order to promote sludge disintegration, the performance of ultrasonic system combined with rotating disk system on sludge disintegration was also investigated.

\section{Materials and Methods}

2.1. Activated Sludge. The inoculation sludge was collected from a WWTP located in Shenyang, China. Then sludge was cultured with Anaerobic/aerobic system in the lab. Mixed liquid suspended solids (MLSS) used in this study were $12000 \pm 50 \mathrm{mg} / \mathrm{L}$.

2.2. Rotating Disk System. Figure 1 illustrated the schematic diagram of rotating disk system. The inner diameter and depth of working cavity were $25 \mathrm{~cm}$ and $40 \mathrm{~cm}$ and total volume of working cavity was about 80 liters. When rotary disk was rotating, sewage sludge between two disks would flow to disk boundary because of centrifugal force. This would make the pressure in central area of rotating disk decrease. Because of pressure difference, sewage sludge under fixed disk would be sucked into treatment area through the hole at the center of disk like a pump; treated sludge flowed into holding tank alone channel where sample can be collected for analysis and returned to working tank as a cycle. Excess sludge treatment process was recycled in this manner by this system. Treatment time was initiated when motor speed reached setting speed.

2.3. Ultrasonic System. Ultrasonic setup was produced by Keer Ltd., energy output ranged from $500 \mathrm{~W}$ to $1000 \mathrm{~W}$, frequency was $20 \mathrm{KHz}$, and probe diameter was $5 \mathrm{~mm}$. The probe was immersed $10 \mathrm{~cm}$ into sludge during excess sludge disintegration process.

2.4. Analysis Methods. SCOD (Soluble Chemical Oxygen Demand) was analyzed according to standard method [10]; DNA (deoxyribonucleic acid) was identified with modified Diphenylamine method [11].

Disintegration parameter $K[12]$ which depicted disintegration effect of excess sludge was defined as follows:

$$
K=\frac{\mathrm{SCOD}_{f}-\mathrm{SCOD}_{i}}{\mathrm{TCOD}-\mathrm{SCOD}_{i}} * 100 \%,
$$

where $K$ is disintegration percentage, $\mathrm{SCOD}_{f}$ is SCOD concentration after disintegration, $\mathrm{SCOD}_{i}$ is $\mathrm{SCOD}$ concentration before disintegration, and TCOD is total COD concentration of excess sludge sample.

\section{Results}

In this study, the effect of distance between disks, feature on disks' surface, and rotating speed on excess sludge disintegration were investigated.

Distances between rotary disk and fixed disk were set as $4.5 \mathrm{~mm}, 3 \mathrm{~mm}$, and $1.5 \mathrm{~mm}$; rotating speed was $2000 \mathrm{rpm}$; sludge samples were collected at $1,3,5,10,15,25$, and 35 minutes when rotating speed reached setting speed. As shown in Figure 2, SCOD concentration during disintegration process increased very fast in first 5 minutes when distance between two disks was $4.5 \mathrm{~mm}$ and SCOD concentration increased 


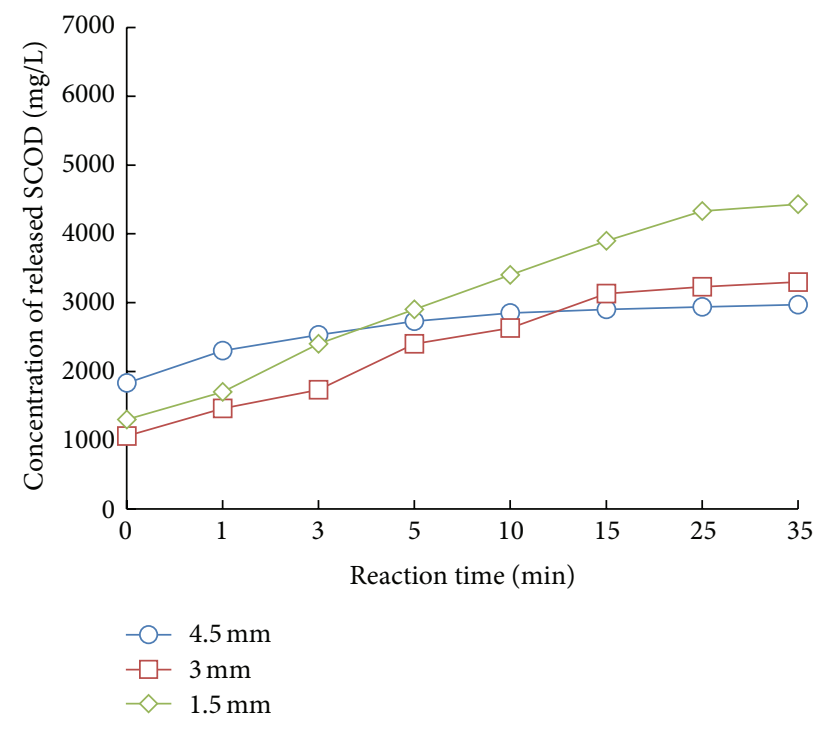

FIGURE 2: Released SCOD during disintegration process with different distances as rotating speed was $2000 \mathrm{rpm}$.

$900 \mathrm{mg} / \mathrm{L}$, whereas the increase of SCOD concentration had almost ceased in the following 30 minutes and SCOD concentration increased only $240 \mathrm{mg} / \mathrm{L}$; total increase of SCOD concentration was $1140 \mathrm{mg} / \mathrm{L}$; when the distance was shortened, SCOD concentration increased sharply and fast. SCOD release had almost ceased until the fifteen minutes. When distance between disks was adjusted to $3 \mathrm{~mm}$, SCOD concentration increased $2070 \mathrm{mg} / \mathrm{L}$ in the first 15 minutes and barely $170 \mathrm{mg} / \mathrm{L}$ in the last 20 minutes; total increase of SCOD concentration was $2240 \mathrm{mg} / \mathrm{L}$. Noteworthy increase of SCOD concentration could be observed when distance of disks was adjusted to $1.5 \mathrm{~mm}$. Increase process had nearly stopped until the 25th minute; SCOD concentration increased $3030 \mathrm{mg} / \mathrm{L}$ and total increase of SCOD concentration was $3130 \mathrm{mg} / \mathrm{L}$. After the treatment in 35 minutes, disintegration parameter $K$ was $15.9 \%, 29.3 \%$, and $41.3 \%$, respectively, when distances between disks were set as $4.5 \mathrm{~mm}, 3 \mathrm{~mm}$, and $1.5 \mathrm{~mm}$. Based on this result, it is obvious that finding shorter distance between disks can improve minimization effect of excess sludge.

In order to improve disintegration effect of WAS with this system, surface of disks was processed as shown in Figure 3. Compared with smooth surface of disks, concavoconvex surface of disks can promote WAS disintegration during treatment because the increase of SCOD concentration during treatment was evidently higher with the same operational parameters.

Figure 4 depicted improvement effect of WAS disintegration with higher rotating speed by this system. Total increase of SCOD concentration was $1650 \mathrm{mg} / \mathrm{L}, 3110 \mathrm{mg} / \mathrm{L}$, and $4420 \mathrm{mg} / \mathrm{L}$ when distance between disks was $4.5 \mathrm{~mm}$, $3 \mathrm{~mm}$, and $1.5 \mathrm{~mm}$ after treatment. Disintegration parameter $K$ increased obviously; it was $23.0 \%, 40.7 \%$, and $58.4 \%$ in the same condition of rotating speed and distances between disks. Features on surface of disks can further promote minimization of excess sludge because disintegration parameter

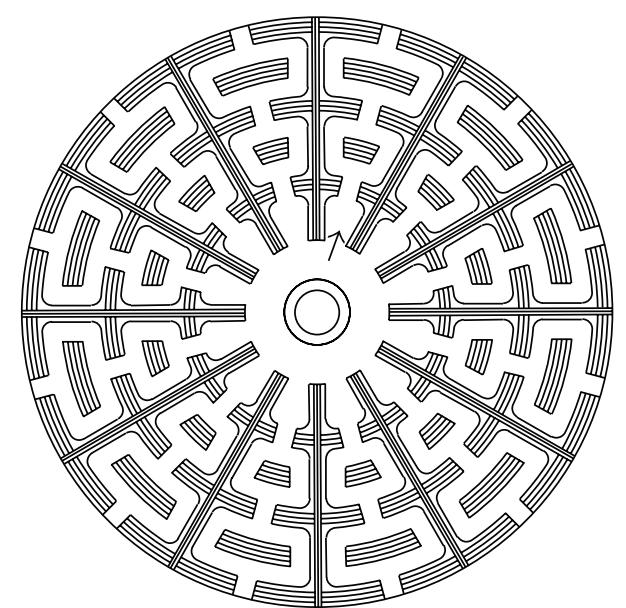

FIGURE 3: Special features on the disks' surface.

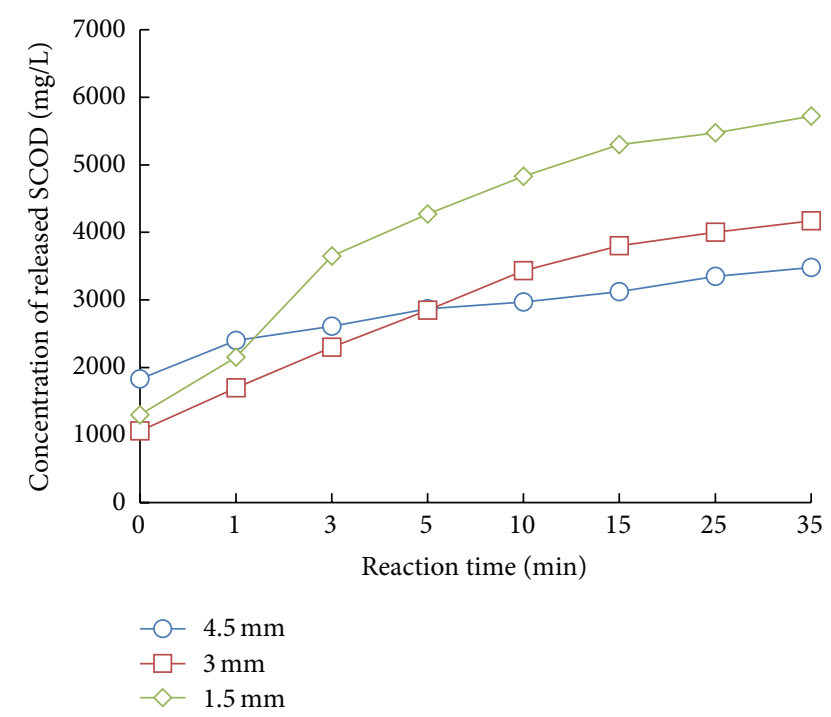

FIGURE 4: Released SCOD during disintegration process with special features on disks as rotating speed was $2000 \mathrm{rpm}$.

$K$ increased $17.1 \%$ compared with smooth surface in the same condition.

Rotating speed would affect flow speed of excess sludge in the treatment area because higher rotating speed would induce bigger velocity gradient in order to produce bigger shear force. Processed surface of disks was applied in this test because of their outstanding performance on excess sludge disintegration. Figure 5 depicted the effect of rotating speed on excess sludge disintegration when rotating speed was adjusted to $4000 \mathrm{rpm}$. The increase of SCOD concentration was very fast and it nearly lasted during whole treatment process. Total increase of SCOD concentration was $2870 \mathrm{mg} / \mathrm{L}, 4540 \mathrm{mg} / \mathrm{L}$, and $5200 \mathrm{mg} / \mathrm{L}$ separately when distance between disks was $4.5 \mathrm{~mm}, 3 \mathrm{~mm}$, and $1.5 \mathrm{~mm}$. Disintegration parameter $K$ can reach $68.7 \%$ when rotating speed was adjusted to $4000 \mathrm{rpm}$ and distance between disks was $1.5 \mathrm{~mm}$. 


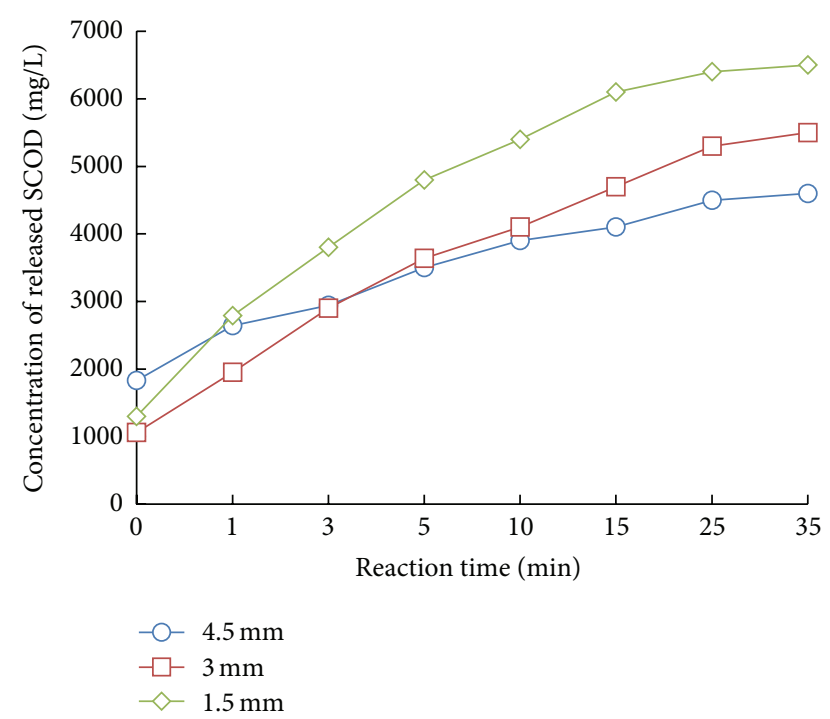

FIGURE 5: Released SCOD during disintegration process with special features on disks as rotating speed was $4000 \mathrm{rpm}$.

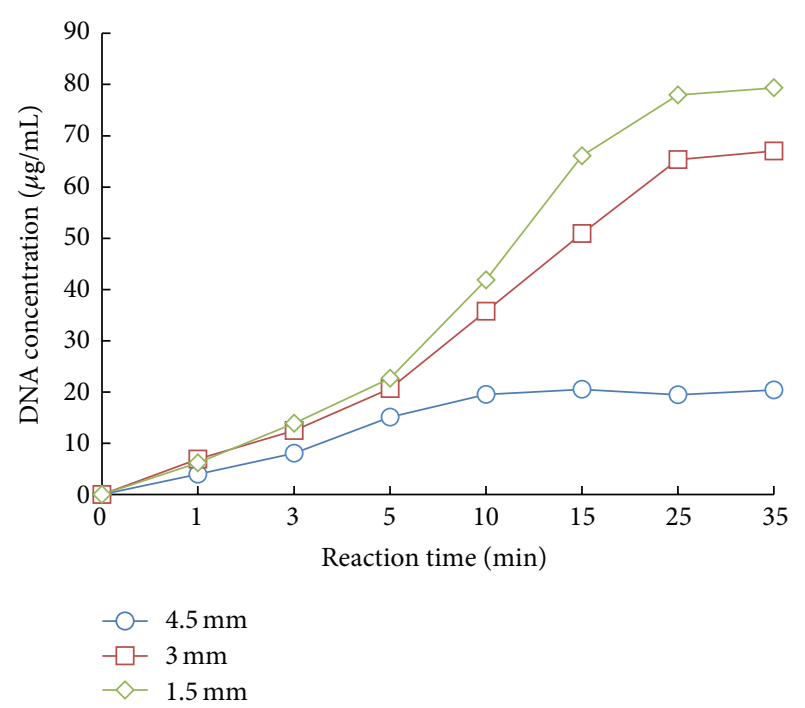

FIGURE 6: The variation of DNA concentration during disintegration process.

Through comparison, $4000 \mathrm{rpm}$ and 35 minutes were chosen as the optimal operation parameters. These parameters were applied in the following analysis.

Most DNA was saved inside the cell; a part of DNA was assembled in the extracellular polymeric substance (EPS). Thus DNA concentration in the solution can be seen as indicator of cell lysis. As shown in Figure 6, when distance of disks was $4.5 \mathrm{~mm}$, increase of DNA concentration was apparent in initial 10 minutes, whereas the increase of DNA concentration almost ceased in the following 25 minutes.

When distance of disks was shorter, DNA concentration increased sharply and the increase process continued in longer time. DNA concentration increased $77.98 \mu \mathrm{g} / \mathrm{mL}$ in 25 minutes as distance of disks was adjusted to $1.5 \mathrm{~mm}$.
TABLE 1: Disintegration effect of rotating disk system and ultrasonic system with different treatment manner.

\begin{tabular}{|c|c|c|}
\hline Treatment manner & SCOD concentration $(\mathrm{mg} / \mathrm{L})$ & Parameter $K$ \\
\hline No treatment & 1300 & \\
\hline $\begin{array}{l}45 \mathrm{~min} \text { by rotating } \\
\text { system }\end{array}$ & 6570 & $69.6 \%$ \\
\hline $\begin{array}{l}45 \text { min by ultrasonic } \\
\text { system }\end{array}$ & 6902 & $74.0 \%$ \\
\hline $\begin{array}{l}35 \text { min by rotating } \\
\text { system combined } \\
\text { with } 10 \text { min by } \\
\text { ultrasonic system }\end{array}$ & 7450 & $81.2 \%$ \\
\hline $\begin{array}{l}15 \text { min by rotating } \\
\text { system combined } \\
\text { with } 10 \text { min by } \\
\text { ultrasonic system }\end{array}$ & 6960 & $74.8 \%$ \\
\hline
\end{tabular}

Increase of DNA concentration was negligible as treatment time exceeded 25 minutes.

Ultrasonic system was tested as the posttreatment for further excess sludge disintegration. Excess sludge sample was treated by ultrasonic system when frequency and power density were $20 \mathrm{KHz}$ and $0.8 \mathrm{~W} / \mathrm{mL}$. In order to make comparison, different manners of treatment process were tested; the result was shown in Table 1.

It is useless to improve sludge disintegration by extending treatment time with rotating disk system when treatment time exceeded 25 minutes, because parameter $K$ was only increased from $68.7 \%$ to $69.6 \%$ when treatment time was extended from 35 minutes to 45 minutes. Ultrasonic system displayed similar performance because parameter $K$ reached $74.0 \%$ after 45 minutes. However, the effect of rotating disk system combined with ultrasonic system on sludge minimization was remarkable because parameter $K$ reached $81.2 \%$ when sludge sample was treated by rotating disk system in 35 minutes then treated by ultrasonic system in 10 minutes. It seems that rotating disk system combined with ultrasonic system had outstanding performance on sludge minimization because parameter $K$ reached $74.8 \%$ when sludge sample was treated by rotating disk system in 15 minutes and ultrasonic system in 10 minutes in consideration of sludge disintegration and energy conservation.

\section{Discussion}

Disintegration parameter $K$ was affected apparently by distance between disks, special features on the surface of disks, and rotating speed in view of experiments' results. In this study, three kinds of distances between disks were investigated. Figure 2 depicted that $K$ was higher when distance between disks was closer; however shorter distance will induce higher torque and less quantity of sewage sludge for treatment; these factors should be taken into account. When the disks' surfaces were machined specially, parameter $K$ was further increased at the same rotating speed $2000 \mathrm{rpm}$ shown in Figure 4. It was very interesting to find that a sharp increase of $K$ appeared in the first 3 minutes. $K$ increased from $41.3 \%$ 
to $58.4 \%$ in the same condition of rotating speed, reaction time, and distances between disks; it means that special machining on the surface of disks can promote disintegration of sewage sludge obviously. The effect of disintegration was more ideal when distance between disks was shorter. Rotating speed was also significant factor which will affect disintegration effect of system. $K$ was increased during whole treatment even though distance between disks was $4.5 \mathrm{~mm}$ as shown in Figure 5. Thus $1.5 \mathrm{~mm}$ distance between disks, $4000 \mathrm{rpm}$ as rotating speed, and special machining on the surface of disks were chosen as optimal parameters for sewage disintegration in this system.

Thin liquid film flow between rotating disks can be encountered in many industrial processes with high rotation rate and consequently high shear rate [13]. This rotating disk system utilized this mechanism and disintegrated sewage sludge by shear force induced by high shear rates. Shorter distance and higher rotating speed can affect shear rates and produce higher shear force which can be used to make cell lysis of sewage sludge. Special features on the surface of disks can increase collision times between samples and disks with high speed which possibly cause damage to cell structure; it probably resulted in improvement on sludge minimization; meanwhile, circuitous channel also prolonged treatment time of sewage sludge in this system.

DNA concentration in solution can provide collateral evidence which can depict degree of cell lysis. As shown in Figure 6, when distance between disks was $4.5 \mathrm{~mm}$, DNA concentration increased nearly $20 \mu \mathrm{g} / \mathrm{mL}$ during 35 minutes, and increasing process had ceased in 10 minutes. Most DNA was saved inside cell, but a small part of DNA was saved in EPS. When distance between disks was $4.5 \mathrm{~mm}$, shear stress was not still sufficient to make cell lysis only decompose EPS even though rotating speed was $4000 \mathrm{rpm}$ and with special machining on surface of disks. DNA concentration increased sharply from 5 th to 25 th minute when distances between disks were $3 \mathrm{~mm}$ and $1.5 \mathrm{~mm}$. This result may illustrate process of cell lysis; shear force which was produced by rotating system firstly decomposed EPS in the first 5 minutes and then broke the cell wall and released intracellular compounds into liquid phase in the following 20 minutes. Similar result was found in other researchers' experiment [14].

Actual power of motor was $15 \mathrm{kw}$ when rotating disk system worked with optimal parameters. Parameter $K$ was very similar when rotating disk system and ultrasonic system worked in the same time shown in Table 1, but power density of rotating disk system was only $0.19 \mathrm{~W} / \mathrm{mL}$ which was much less than ultrasonic system. Low energy demand was very obvious compared with ultrasonic system. Besides, no chemical reagents consumption, simple operation, and treatment ability of large quantity excess sludge were also advantages compared with other sludge disintegration methods.

Combination of rotating disk system and ultrasonic system for sewage disintegration was investigated in this study shown in Table 1. Because of these combined treatments, disintegration effect was ideal; $K$ reached $81.2 \%$ when sample was treated by rotating disk system for 35 minutes and then ultrasonic system for 10 minutes. It was worthy to note that obvious increase of $K$ could not be realized by prolonging treatment time of rotating disk system in this combined treatment. In view of this study, combination of rotating disk system and ultrasonic system had outstanding effect on sludge disintegration because this combined system can have better disintegration effect of excess sludge in less time with energy conservation.

\section{Conclusion}

Rotating disk system had very impressive performance on disintegration of excess sludge; disintegration parameter $K$ can reach $68.7 \%$ with optimal parameters by this system. Closer distance and higher rotating speed can effectively promote disintegration effect of excess sludge. Special features on surfaces of disks had outstanding performance to improve disintegration effect of excess sludge during treatment. Combination of rotating disk system and ultrasonic system can realize better disintegration effect in shorter time. Consequently, rotating disk system was a promising technique for minimization of excess sludge.

\section{Competing Interests}

The authors declare that they have no competing interests.

\section{Acknowledgments}

This research was supported by the university-industry cooperation programs of Guangdong province, no. 2013B090900001.

\section{References}

[1] J. L. Campos, L. Otero, A. Franco, A. Mosquera-Corral, and E. Roca, "Ozonation strategies to reduce sludge production of a seafood industry WWTP," Bioresource Technology, vol. 100, no. 3, pp. 1069-1073, 2009.

[2] Y. Tian, J. Zhang, D. Wu, Z. P. Li, and Y. N. Cui, "Distribution variation of a metabolic uncoupler, 2,6-dichlorophenol (2,6DCP) in long-term sludge culture and their effects on sludge reduction and biological inhibition," Water Research, vol. 47, no. 1, pp. 279-288, 2013.

[3] T. Mahmood and A. Elliott, "A review of secondary sludge reduction technologies for the pulp and paper industry," Water Research, vol. 40, no. 11, pp. 2093-2112, 2006.

[4] J. Q. Lou, P. D. Sun, M. X. Guo, G. Wu, and Y. Q. Song, "Simultaneous sludge reduction and nutrient removal (SSRNR) with interaction between Tubificidae and microorganisms: a fullscale study," Bioresource Technology, vol. 102, no. 24, pp. 1113211136, 2011.

[5] S. Saby, M. Djafer, and G.-H. Chen, "Feasibility of using a chlorination step to reduce excess sludge in activated sludge process," Water Research, vol. 36, no. 3, pp. 656-666, 2002.

[6] G. Wang, J. Sui, H. Shen et al., "Reduction of excess sludge production in sequencing batch reactor through incorporation of chlorine dioxide oxidation," Journal of Hazardous Materials, vol. 192, no. 1, pp. 93-98, 2011. 
[7] X.-S. Guo, J.-X. Liu, Y.-S. Wei, and L. Li, "Sludge reduction with Tubificidae and the impact on the performance of the wastewater treatment process," Journal of Environmental Sciences, vol. 19, no. 3, pp. 257-263, 2007.

[8] Y. S. Wei, Y. W. Wang, X. S. Guo, and J. X. Liu, "Sludge reduction potential of the activated sludge process by integrating an oligochaete reactor," Journal of Hazardous Materials, vol. 163, no. 1, pp. 87-91, 2009.

[9] I. Doğan and F. D. Sanin, "Alkaline solubilization and microwave irradiation as a combined sludge disintegration and minimization method," Water Research, vol. 43, no. 8, pp. 21392148, 2009.

[10] APHA, AWWA, and WEF, Standards Methods for the Examination of Water and Wastewater, vol. 5, 19th edition, 1995.

[11] L.-X. Zhang and T.-F. Zhang, Biochemical Experiment and Technology, Chemical Engineering Publishing House, 2nd edition, 1998 (Chinese).

[12] E. Zielewicz, "Effects of ultrasonic disintegration of excess sewage sludge," Applied Acoustics, vol. 103, pp. 182-189, 2016.

[13] G. Leneweit, D. Fröse, K. G. Roesner, R. Koehler, and A. Scheffler, "Shear degradation and deformation of polysaccharides in thin liquid film flow on a rotating disk," Polymer Degradation and Stability, vol. 70, no. 2, pp. 283-297, 2000.

[14] P. Kampas, S. A. Parsons, P. Pearce et al., "Mechanical sludge disintegration for the production of carbon source for biological nutrient removal," Water Research, vol. 41, no. 8, pp. 1734-1742, 2007. 

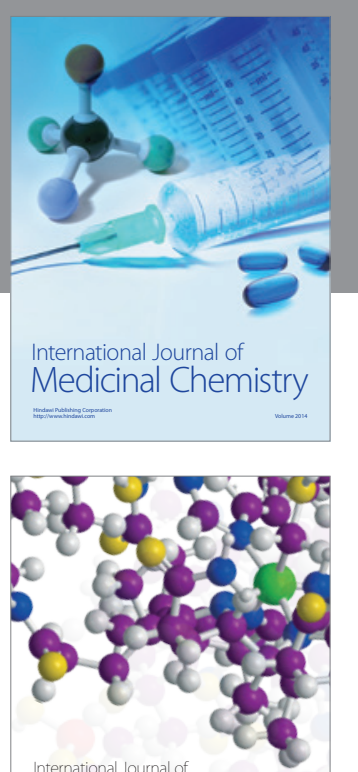

Carbohydrate Chemistry

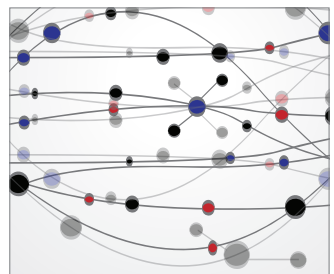

The Scientific World Journal
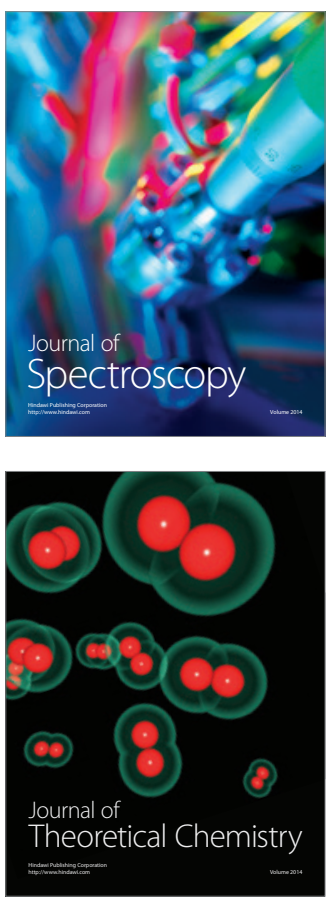
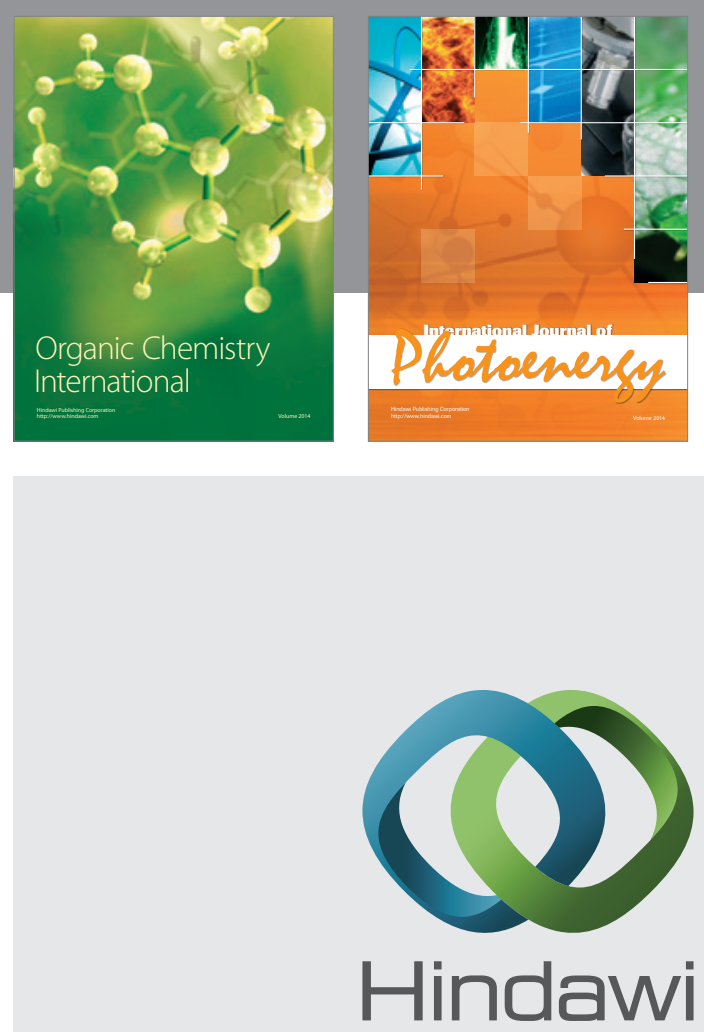

Submit your manuscripts at

http://www.hindawi.com

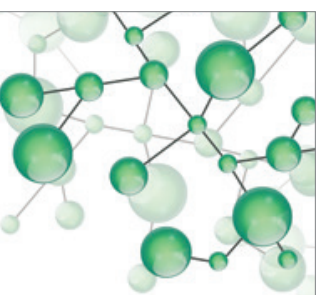

International Journal of

Inorganic Chemistry

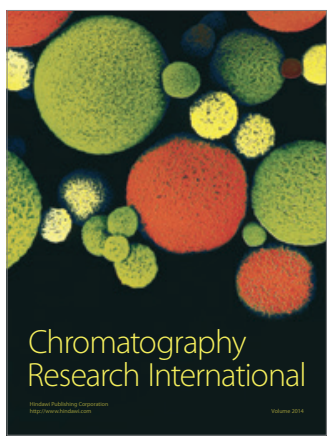

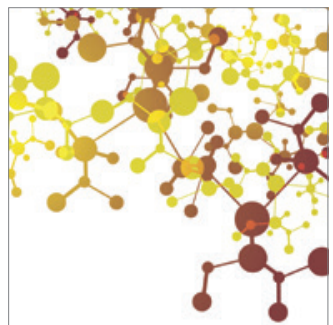

Applied Chemistry
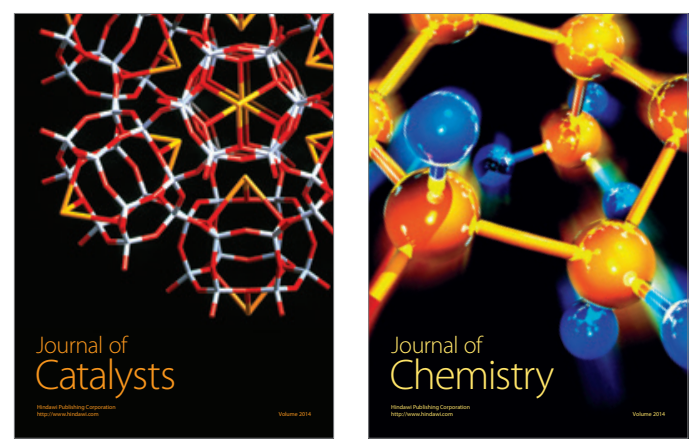
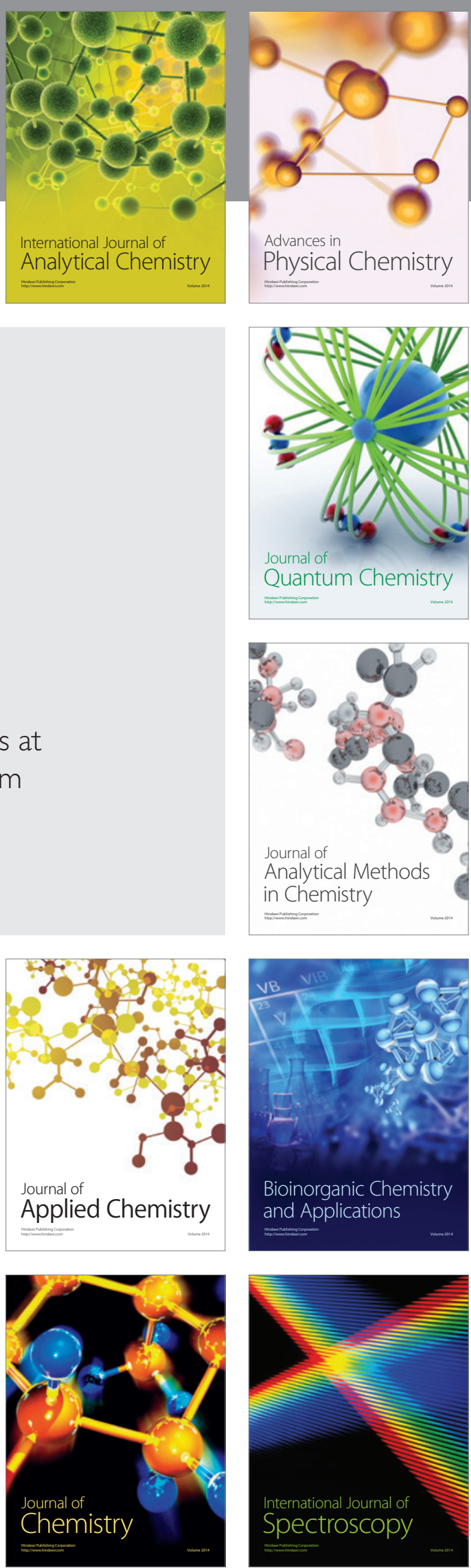